\title{
IAMJ
}

INTERNATIONAL

AYURVEDIC

MEDICAL JOURNAL

\section{A CRITICAL REVIEW ON VRISHCHIKA VISHA: AN AYURVEDIC CONCEPT}

\author{
Prema Ekka $^{1^{*}}$, Inchulkar ${ }^{2}$, Sangeeta Bhagat ${ }^{3}$ \\ ${ }^{1}$ PG Scholar, ${ }^{2}$ Professor \& H.O.D., ${ }^{3}$ Lecturer, \\ Department of Agad Tantra Evum Vidhi Ayurved, Govt. Ayurved College, Raipur (CG), India
}

Corresponding Author: prema.ekka01@gmail.com

https://doi.org/10.46607/iamj1609042021

(Published Online: April 2021)

Open Access

(C) International Ayurvedic Medical Journal, India 2021

Article Received: 20/03/2021 - Peer Reviewed: 13/04/2021 - Accepted for Publication: 15/04/2021

Check for updates

\begin{abstract}
Ayurveda is the Oldest, Traditional, Indian System of Health Science. It gives the knowledge of longevity and healthy life. Thus 'Ayurveda' totally means 'Science of life' having the eight main branches. Agadatantra is one among the main branch which deals with the study of poisons (Toxicology), their signs and symptoms, fatal dose, antidotes and management. Acharya Sushruta has described in detail about all the keeta visha in Kalpa Sthana of Sushruta Samhita, Vriddha Vagbhata in Uttaratantra of Ashtanga Sangraha, Laghu Vagbhata in Uttaratantra of Ashtanga Hridaya and in other Ayurvedic classics and textbook. Vrishchika (Scorpion) is one among keeta visha. It is mainly neurotoxic in nature especially belonging to the buthidae family are more dangerous to the human. It causes severe pain, burning sensation, swelling and redness at the site of bite. According to its severity, Acharya's have described all the type of vrishchikas, their signs and symptoms, complications and treatment.
\end{abstract}

Keywords: Ayurveda, Visha, Vrishchika visha, Scorpion poison

\section{INTRODUCTION}

Vrishchika (Scorpion) is very dangerous to the living body. It is having almost 3-7 inch long. The body of the scorpion is divided into two parts. They have eight legs and six segments on the tail. The last segment is known as telson and venom apparatus is present in the last segment. According to Ayurveda they are originated from goshakrit, kashtheshtiha and sarpa. Acharya Sushruta, has classified visha into two types 
i.e. Sthavara visha (plant poison) and Jangama visha (animal poison) ${ }^{[1]}$. Here Vrishchika has been mentioned under the jangama visha in keeta prakaran. Acharya Sushruta, has mentioned 16 adhisthanas (sites) of jangama visha. Vrishchika is a keeta and its adhisthana is shooka (sting) ${ }^{[2]}$.

Synonyms:- Acc. to Raj Nighantu, Synonyms of Vrishchika $\operatorname{are}^{[3]}$ -

1. Shooka keeta

2. Alidrona

\section{Aim and Objectives}

- To evaluate and discuss about Vrishchika visha their sign, symptoms, effect on body and treatment.

- To study about all the types of Vrishchika described in our Samhita Granthas and Ayurvedic texts.

\section{Material and Methods:}

The detail study on Vrishchika visha and their effect on human body is done with the help of our Samhitas especially in Sushruta Samhita and Ayurvedic textbooks.

\section{Historical Review $^{[4]}$}

1) Vedic Kala:- 'Veda' is the first source of literature and knowledge that narrates medical science very cogently. Detail explanations about several keetas have been mentioned in yajurveda.

2) Samhita Kala:- Samhita kala is considered as golden age of Ayurvedic history.

Charaka Samhita:- Charaka Samhita is considered as one of the best Samhita, which explains the chikitsa (treatment) of several diseases. The context of vrishchika has been explained under $23^{\text {rd }}$ chapter of chikitsa sthana.

Sushruta Samhita:- Sushruta Samhita has rendered one whole sthana i.e. kalpa sthana for visha chikitsa. Acharya sushruta has been explained in detail about vrishchika under $8^{\text {th }}$ chapter, keeta kalpa adhyaya of kalpa sthana.

Harita Samhita:- In Harita Samhita, $55^{\text {th }}$ chapter of $3^{\text {rd }}$ sthana, mantra chikitsa has been mentioned for the management of Vrishchika damsha.

\section{3) Sangraha Kala:-}

Ashtanga Sangraha:- Acharya Vriddha Vagbhat has been elaborated the details of Vrishchika in sarpa visha pratishedha adhyaya (42 ${ }^{\text {nd }}$ chapter), Keeta Visha Pratishedha Adhyaya (43 ${ }^{\text {rd }}$ chapter) and Visha Opayogiya Adhyaya ( $48^{\text {th }}$ chapter) of Uttaratantra.

Ashtanga Hridaya:- Acharya Vagbhat has also mentioned the context of Vrishchika in $36^{\text {th }}$ and $37^{\text {th }}$ chapter of Uttaratantra.

\section{Utpatti (Origin) Of Vrishchika ${ }^{[5]}$}

Acc. to Acharya Sushruta the origin of Vrishchikas are said to be 3 types i.e. manda, madhyama and mahavisha. The one which are originated from Goshakrit (putrefied cowdung) called manda visha, those from Kashtha (wood) and eshtikas (bricks) are called madhyma visha and those are originated from Sarpa (cadaver of snakes) are called mahavisha.

\section{Types $^{[6]}$}

Acc. to their origin as well as its toxicity, Vrishchikas are classified into 3 types:-
1. Manda Visha
2. Madhyama Visha
3. Maha Visha

\section{Number of Vrishchikas}

Acc. to Acharya Sushruta, there are total 30 in number $^{[7]}:-$

(1) Manda Visha - 12, (2) Madhyama Visha - 3, (3) Mahal Teekshna Visha - 15

Acc. to Acharya Charaka ${ }^{[8]}$ :-

There are two in number :-

(1) Dooshi visha

(2) (2) Pranahara or Asadhya visha.

In Prayoga Samuchaya ${ }^{[9]}$ :-

There are mainly four in numbers :-

(1) Vaataja (2) Pittaja (3) Kaphaja (4) Sannipataja.

Acc. to Kriya Kaumudi :-

(1) Vaayavya -1, (2) Aagneya-2, (3) Soumya-13, (4) Sankirna-12

Acc. to Gayadas ${ }^{[10]}$ :-

(1) Manda-10, (2) Madhyama-3, (3) Pranahara-13 
Table 1: According to Acharya Sushruta, the three types of Vrishchika are as follows ${ }^{[11]}$

\begin{tabular}{|l|l|l|}
\hline Maha Visha & Madhya Visha & Manda Visha \\
\hline Shweta & Rakta & Krishna \\
\hline Chitra & Peeta & Shyaava \\
\hline Lohitabha & Kapila & Karbura \\
\hline Raktasweta & - & Pandu varna \\
\hline Raktodara & - & Gomootrabh \\
\hline Neelodara & - & Karkasha \\
\hline Peeta rakta & - & Mechaka \\
\hline Neela rakta & - & Peeta \\
\hline Neela sweta & - & Dhoomra varna \\
\hline Rakta vabhru & - & Romasha \\
\hline Eka parva & - & Shadvalabh \\
\hline Dwiparva & - & Rakta \\
\hline Aparva & - & - \\
\hline Shyamala & - & - \\
\hline Neela peeta & - & - \\
\hline
\end{tabular}

\section{General Symptoms Of Bite Of Vrishchika Visha ${ }^{[12]}$}

Most of the scorpions are neurotoxic in nature and causes locally severe pain (vedana), burning sensation (daha), swelling (shotha) and redness at the site of bite. The patient suffers from above symptoms and pain moves in upward direction from the site of bite. According to Acharya Vriddha Vagbhata, the bite of poisonous scorpion is similar to fire, suddenly pain moves in upward direction and later on it fixed at the site of bite. The bitten site becomes blackish in colour and unbearable pain and burning sensation is present at the site.
Acharya Charaka has been explained the symptoms of dooshi visha and pranahara. The bite of dooshi visha scorpion is similar to fire and there will be burning sensation and bhednavat pida (piercing pain) at the site of bite and pain moves in upward direction. When bitten by pranahara vrishchika, there will be loss of sensation of eyes, nose, tongue and flesh cut and fall from the site of bite and excessive pain also present at the site of bite. Because of all these symptoms, human souls perish. Pranahara visha is also known as asadh$y a^{[13]}$.

\section{Types of Vrishchika Visha}

Table 2: Based on Swaroopa (Physical Appearance and Varna (Colour) ${ }^{[14]}$

\begin{tabular}{|c|c|c|c|c|}
\hline S.No. & Vrishchika Bheda & Varna & Swaroopa & Samanya Lakshana \\
\hline 1 & $\begin{array}{l}\text { Manda Visha Vri- } \\
\text { shchika }\end{array}$ & $\begin{array}{l}\text { - Krishna } \\
\text { - Shyava } \\
\text { - Karbura } \\
\text { - } \quad \text { Pandu } \\
\text { - Gomootra } \\
\text { - Karkasha } \\
\text { - Mechaka } \\
\text { - Peeta } \\
\text { - Dhooma Varna } \\
\text { - Romayukta } \\
\text { - Shadvala }\end{array}$ & $\begin{array}{l}\text { - Possess In Tail Bahu } \\
\text { Parva (Many Joints) } \\
\text { - They Have Shweta } \\
\text { Udara (White Abdo- } \\
\text { men) }\end{array}$ & $\begin{array}{l}\text { - } \quad \text { Kedana } \\
\text { - Kampa } \\
\text { - Kaatra Stambha } \\
\text { - Krishna Rakta } \\
\text { - Daha } \\
\text { - Shotha } \\
\text { - Jwara } \\
\text { - Sweda }\end{array}$ \\
\hline
\end{tabular}




\begin{tabular}{|c|c|c|c|c|}
\hline & & - Rakta Varna & & \\
\hline 2 & $\begin{array}{l}\text { Madhyama Visha } \\
\text { Vrishchika }\end{array}$ & $\begin{array}{l}\text { - Rakta } \\
\text { - Peeta }\end{array}$ & $\begin{array}{l}\text { - Possess In Tail Tri } \\
\text { Parva (Three Joints) } \\
\text { - Udara Having Kapila } \\
\text { Or Krishna Varna }\end{array}$ & $\begin{array}{l}\text { - Jihva Shotha } \\
\text { - Difficulty In Swallow- } \\
\text { ing Of Food } \\
\text { - Moorchha }\end{array}$ \\
\hline 3 & $\begin{array}{l}\text { Maha Vish Vris- } \\
\text { chika }\end{array}$ & $\begin{array}{ll}\text { - } & \text { Shweta } \\
\text { - } & \text { Chitra } \\
\text { - } & \text { Shyamala } \\
\text { - } & \text { Lohita } \\
\text { - } & \text { Rakta Shweta } \\
\text { - } & \text { Rakta Neela } \\
\text { - } & \text { Peeta Rakta } \\
\text { - } & \text { Neela Peeta } \\
\text { - } & \text { Neela Shukla } \\
\text { - } & \text { Rakta Vabru }\end{array}$ & $\begin{array}{ll}\text { - } & \text { Eka Parva Or Dwi } \\
\text { Parva Or Aparva } & \\
\text { - Nana-Aakruti } & \text { Or } \\
\text { Nana-Varna }\end{array}$ & $\begin{array}{ll}\text { - } & \text { Sarpa Visha Vega } \\
\text { - } & \text { Sphota } \\
\text { - } & \text { Daha } \\
\text { - } & \text { Jwara } \\
\text { - } & \text { Manovibhram }\end{array}$ \\
\hline
\end{tabular}

\section{Acc. To Kriya Kaumudi ${ }^{[15]}$}

Table 3: Dosha wise Varna Lakshna of Vrishchika Visha

\begin{tabular}{|l|l|l|}
\hline No. & Type & Varna Lakshna \\
\hline 1 & Vaayavya & Severe pain, Pricking pain \\
\hline 2 & Aagneya & Burning sensation, redness, slight oedema, kharjura varna \\
\hline 3 & Soumya & Continuous thick blood discharge, alpa vedana, udumbara varna \\
\hline 4 & Sankirna & All type of symptoms are seen \\
\hline
\end{tabular}

\section{Acc. To Prayoga Samuchchaya And Kriya Kaumudi ${ }^{[16]}$}

Table 4: Dhatugata Lakshna of Vrishchika Visha

\begin{tabular}{|l|l|l|l|}
\hline No. & Dhatu & Prayoga Samuchchaya & Kriya Kaumudi \\
\hline 1 & Twak & Severe pain & Pricking pain, vomiting, delirium, convulsion \\
\hline 2 & Rakta & Severe burning sensation & All above + fatigue, burning sensation, jwara, atisaara \\
\hline 3 & Mamsa & Hidhma, Oedema & Granthi all over body \\
\hline 4 & Meda & Greevabhanga & Hidma, Galashosha \\
\hline 5 & Asthi & Jwara & Jwara \\
\hline 6 & Majja & Manastaapa, Dukha & Vyasana manastaapa \\
\hline 7 & Shukra & Rakta netra, Death & Rakta netra Death \\
\hline
\end{tabular}

Acc. To Acharya Vagbhata ${ }^{[17]}$

Table 5: Based on doshapradhana Vrishchika Visha Lakshna

\begin{tabular}{|l|l|l|}
\hline S. No. & DOSHA & LAKSHNAS \\
\hline 1 & Vataja & Hrutpida, Stambha, Urdhwaswasa, Asthi and Parva vedana etc. \\
\hline 2 & Pittaja & Sanyanasa, Hridaya daha, Shotha, Rakta-Pitta Roga etc. \\
\hline 3 & Kaphaja & Vamana, Arochaka, Lalashrava, Sweda, Sheetala, Peenasa, Mukhamadhurya. \\
\hline
\end{tabular}




\section{Asadhya (Incurable) Lakshnas of Vrishchika Vi- sha $^{[18,19]}$}

Acc. to Acharya Charaka, he has described the symptoms of scorpion bite which are clinically incurable i.e. Loss of function of heart, nose and tongue

Loss of muscle tissues

Excruciating pain.

Treatment of Vrishchika Visha ${ }^{[20,21]}$

Acharya Charaka has explained the general treatment of Vrishchika visha is Swedana (sudation), Abhyanga with Ghrita and Sandhava, Parisheka (irrigation), food along with ghrita.

According to Acharya Sushruta the treatment of Ugra and Madhyama types of Vrishchika should be done similarly to Sarpadashta (Snake bite). Site of the sting should be cleaned properly and then Swedana should be done. Pratisarana should be done by Haridra, Saindhava Lavana, Trikatu and Churna of Shirisha phala and pushpa.

\section{Upadravas (Complications) of Vrishchika Visha ${ }^{[22]}$}

Ayurvedic texts like Prayoga Samuchchaya and Kriya Kaumudi has explained about the upadrava of vrishchika visha, which may appear due to the bite of ugravisha vrischika. These complications are:Asahyavedana (severe pain)

Shotha (swelling)

Shwasa (breathlessness)

Trishna (thirst)

Moha and Pralapa (delirium)

\section{Upadrava Chikitsa}

1. Lepa - Churna of Vibhitaki, Haridra, Pippali, Manjistha, Maricha and Visha should be grinded in the swarasa of Brihati and it should be applied in the form of lepa.

2. Pana - Dadhi and Ghrita should be taken in the form of pana.

3. Anjana - Karanja, Tintidika, Saindhava and Karaskarapatra swarasa should be taken in the form of anjana.

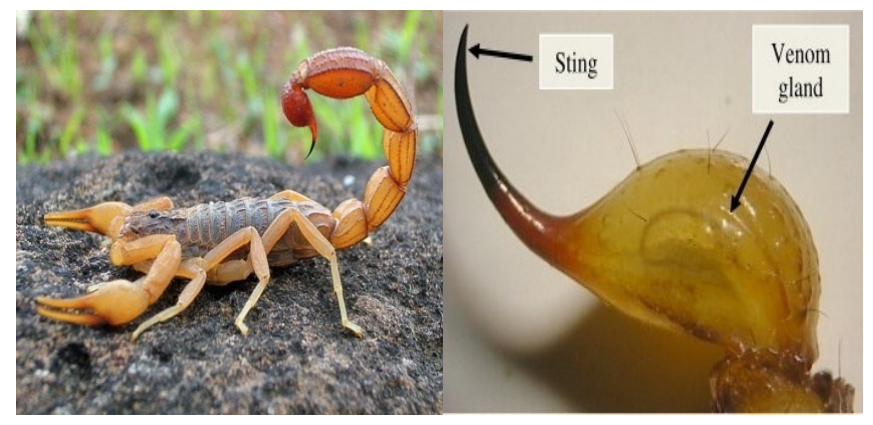

Figure 1: Vrishchika (Scorpion poison)

\section{DISCUSSION AND CONCLUSION}

Scorpions are venomous in nature especially which are belonging to buthidae family. Majority of species do not represent serious life threat to the human, only about 25 species have venom capable of killing a human. Acharyas have described in detail about its physical appearance, classification, numbers, sign and symptoms, mode of action of venom, complications and management. In literature and textbooks, the various types of Vrishchika visha are described by our Acharyas. They are dangerous to the human beings. So, the treatment is very important. According to Dosha, Acharyas have mentioned several Dravyas and
Yogas in the form of Pana, Lepa, Dhupana, Mantra Chikitsa etc. for the treatment of Vrishchika Damsha. The observation by the Acharyas can help us to manage the treatment of Vrishchika visha. Though in this article efforts have been made to compile the various types of Vrishchika, their classification, features to identify the various Vrishchikas, their clinical manifestation and treatment. 


\section{REFERENCES}

1. Acharya Sushruta - Sushruta Samhita of Maharsi Susruta by Kaviraj Ambikadutta Shastri, part-1 published by Chaukhambha Sanskrit Sansthan, Reprint2016. (Pg-18, 2/3)

2. Acharya Sushruta - Sushruta Samhita of Maharsi Susruta by Kaviraj Ambikadutta Shastri, part-1 published by Chaukhambha Sanskrit Sansthan, Reprint2016. (Pg-38,3/4)

3. Dr. Ayodhya Prasad Achal, Textbook of Agada tantra, published by Chaukhambha Surbharati Prakashan $2^{\text {nd }}$ Edition-2017. (Pg-170)

4. Dr. Nitin Urmaliya, Textbook of Agada Tantra, Chaukhambha Orientalia, $1^{\text {st }}$ Edition-2011. (Pg-197-198)

5. Acharya Sushruta - Sushruta Samhita of Maharsi Susruta by Kaviraj Ambikadutta Shastri, part-1 published by Chaukhambha Sanskrit Sansthan, Reprint2016. (Pg-89, 8/56-57)

6. Dr. Ayodhya Prasad Achal, Textbook of Agada tantra, published by Chaukhambha Surbharati Prakashan $2^{\text {nd }}$ Edition-2017. (Pg-170)

7. Acharya Sushruta - Sushruta Samhita of Maharsi Susruta by Kaviraj Ambikadutta Shastri, part-1 published by Chaukhambha Sanskrit Sansthan, Reprint2016. (Pg-89, 8/58)

8. Acharya Charaka - Charaka Samhita of Agnivesa by Bramhanand Tripathi, part-2, published by Chaukhamba Surbharati Prakashan Varanasi. (Pg-777$778,23 / 140)$

9. Dr. Nitin Urmaliya, Textbook of Agada Tantra, Chaukhambha Orientalia, ${ }^{\text {st }}$ Edition-2011. (Pg-200)

10. Acharya Sushruta - Sushruta Samhita of Maharsi Susruta by Kaviraj Ambikadutta Shastri, part-1 published by Chaukhambha Sanskrit Sansthan, Reprint2016. (Pg-89, chap-8)

11. Dr. Anita Sharma, Textbook of Agad Tantra Vigyan, Chaukhambha Orientalia Varanasi, $1^{\text {st }}$ Edition-2016. (Pg-186)

12. Acharya Vriddha Vagbhata - Astanga Samgraha by Kaviraja Atrideva Gupta published by Chaukhambha Prakashan Varanasi, Reprint-2016. (Pg-364, 43/21)

13. Dr. Sachin Kumar Baghel, Dr. Shrikant R. Inchulkar, Dr. Subhash R. Gharde, Textbook of Agada Tantra Evam Visha Vigyana, published by Vaibhav Prakashan, $1^{\text {st }}$ Edition-2017. (Pg-121-122)

14. Dr. Ayodhya Prasad Achal, Textbook of Agada Tantra, published by Chaukhambha Surbharati Prakashan $2^{\text {nd }}$ Edition-2017. (Pg-171-172)
15. Dr. Nitin Urmaliya, Textbook of Agada Tantra, Chaukhambha Orientalia, $1^{\text {st }}$ Edition-2011. (Pg-205-206)

16. Dr. Nitin Urmaliya, Textbook of Agada Tantra, Chaukhambha Orientalia, $1^{\text {st }}$ Edition-2011. (Pg-206)

17. Acharya Vriddha Vagbhata - Astanga Samgraha by Kaviraja Atrideva Gupta published by Chaukhambha Prakashan Varanasi, Reprint-2016. (Pg-365, 43/33-35)

18. Acharya Charaka - Charaka Samhita of Agnivesa by Bramhanand Tripathi, part-2, published by Chaukhamba Surbharati Prakashan Varanasi. (Pg-780-781, 23/151)

19. Dr. Ayodhya Prasad Achal, Textbook of Agada tantra, published by Chaukhambha Surbharati Prakashan $2^{\text {nd }}$ Edition-2017. (Pg-173-174)

20. Acharya Charaka - Charaka Samhita of Agnivesa by Bramhanand Tripathi, part-2, published by Chaukhamba Surbharati Prakashan Varanasi. (Pg-786, 23/173)

21. Acharya Sushruta - Sushruta Samhita of Maharsi Susruta by Kaviraj Ambikadutta Shastri, part-1 published by Chaukhambha Sanskrit Sansthan, Reprint2016. (Pg-92, 8/67)

22. Dr. Nitin Urmaliya, Textbook of Agada Tantra, Chaukhambha Orientalia, $1^{\text {st }}$ Edition-2011. (Pg-208)

\section{Source of Support: Nil \\ Conflict of Interest: None Declared}

How to cite this URL: Prema Ekka et al: A Critical Review On Vrishchika Visha: An Ayurvedic Concept. International Ayurvedic Medical Journal \{online\} 2021 \{cited April, 2021\} Available from: http://www.iamj.in/posts/images/upload/788 793.pdf 